\title{
Bone morphogenetic proteins: From discovery to development of a novel autologous bone graft substitute consisting of recombinant human BMP6 delivered in autologous blood coagulum carrier
}

OPEN ACCESS

Correspondence:

Slobodan Vukičević

Lovorka Grgurević slobodan.vukicevic@mef.hr lovorka.grgurevic@mef.hr orcid.org/0000-0003-2050-5308 orcid.org/0000-0002-9814-3178

This article was submitted to RAD CASA - Medical Sciences as the original article

Conflict of Interest Statement: The authors declare that the research was conducted in the absence of any commercial or financial relationships that could be construed as a potential conflict of interest.

Received: 16 November 2020 Accepted: 4 December 2020 Accepted: 4 December 2020
Published: 28 December 2020 Vukičević S, Perić M, Oppermann H. et al. Bone morphogenetic proteins: From discovery to development of a novel autologous bone graft substitute consisting of recombinant human BMP6 delivered in autologous blood coagulum carrier

RAD CASA - Medical Sciences. 544=52-53 (2020): 26-41 DOI: https://dx.doi.org/10.21857/ mnlqge5vgy

Copyright (C) 2020 Vukičević S, Perić $\mathrm{M}$, Oppermann $\mathrm{H}$. et al. This is an open-access article distributed under the terms of the Creative Commons Attribution License (CC BY). The use, distribution or reproduction in other fistribution or reproduction in othe forums is permitted, provided the original author(s) and the copyright owners(s) are credited and that the original publication in this journal is cited, in accordance whit accepted adacemic practice. No use, distribution or reproduction is permitted which does not comply with these terms.
Slobodan Vukičević, ${ }^{1,2}$, Mihaela Periće, ${ }^{2,3}$ Hermann Oppermann ${ }^{4}$, Nikola Stoković ${ }^{1,2}$, Natalia Ivanjko ${ }^{1,2}$, Igor Erjavec ${ }^{1,2}$, Vera Kufner ${ }^{1,2}$, Dražen Vnuk ${ }^{5}$, Jadranka BubićŠpoljar ${ }^{1,2}$, Marko Pećin ${ }^{5}$, Ruđer Novak ${ }^{1,2}$, Ivona Matić Jelić ${ }^{1,2}$, Kristian Bakić, ${ }^{1,2}$, Marina Milešević, ${ }^{1,2}$, Viktorija Rumenović ${ }^{1,2}$, Irena Popek ${ }^{4}$, Sanja Pehar ${ }^{1,2}$, Snježana Martinović $^{6}$, Valentina Blažević, ${ }^{1,2}$, Lucija Rogina ${ }^{1,2}$, Smiljka Vikić-Topić ${ }^{7}$, Tamara Božić $^{4}$, Donatella Verbanac ${ }^{2,3 \#}$, Tatjana Bordukalo Nikšićc ${ }^{1,2}$, T. Kuber Sampath ${ }^{8}$, Marko Pećina ${ }^{9}$, Dražen Matičićs ${ }^{2}$ and Lovorka Grgurević ${ }^{1,2}$

\footnotetext{
Laboratory for Mineralized Tissues, Centre for Translational and Clinical Research. University of Zagreb School of Medicine, Zagreb, Croatia

Scientific Center of Excellence for Reproductive and Regenerative Medicine, Zagreb, Croatia

Department for Intracellular Communication, Centre for Translational and Clinical Research, University of Zagreb School of Medicine, Zagreb, Croatia

Genera Research, Kalinovica, Rakov Potok, Croatia

Clinics for Surgery, Orthopedics and Ophthalmology, School of Veterinary Medicine, University of Zagreb, Zagreb, Croatia

6 SmartMedico, Zagreb, Croatia

Research and Technology Transfer Office, Center for Translational and Clinical Research, University of Zagreb School of

Medicine, Zagreb, Croatia

${ }^{8}$ perForm Biologics Inc, Holliston, Massachusetts, USA

Department of Orthopaedic Surgery, University of Zagreb School of Medicine, Zagreb, Croatia

* Current affiliation: University of Zagreb Faculty of Pharmacy and Biochemistry
} 
and better microarchitecture of the newly formed bone. The first clinical study was conducted in patients with distal radial fractures (Phase I study) and the second in patients undergoing high tibial osteotomy (Phase I/II study) and no serious adverse events have been observed. Finally, in the ongoing OSTEOproSPINE study ABGS enforced with allograft bone is evaluated in patients with chronic back pain due to degenerative disc diseases. The novel ABGS bone mimetic is a major breakthrough and contribution to bone biology and regenerative medicine of skeletal repair.

KEYWORDS: BMP6, TGF $\beta$ superfamily, endochondral bone formation, bone mimetic, distal radial fracture, high tibial osteotomy, posterolateral lumbar spine fusion, allograft, chronic lumbar back pain, regenerative medicine

\section{SAŽETAK:}

KOŠTANI MORFOGENETSKI PROTEINI (BMP): OD OTKRIĆA DO RAZVOJA NOVE AUTOLOGNE KOŠTANE NAPRAVE KOJA SE SASTOJI OD REKOMBINANTNOG HUMANOG BMP6 U AUTOLOGNOM KRVNOM UGRUŠKU KAO NOSAČU

Koštani morfogenetski proteini (BMP) čine grupu čimbenika rasta i diferencijacije unutar TGF $\beta$ nadobitelji. Oni induciraju stvaranje ektopične i ortotopične endohondralne kosti te su uključeni u regulaciju stanične proliferacije, diferencijacije, apoptoze i mezenhimalno-epitelne interakcije u važnim tkivnim morfogenetskim procesima izvan koštanog sustava. Koštane naprave koje sadrže BMP2 i BMP7 protein odobrene su za poboljšanje koštanog cijeljenja kod pacijenata s defektima dugih cjevastih kostiju i kod prednje spinalne fuzije kralježnice. Međutim, zbog visoke cijene i mnogobrojnih nuspojava koje su uključivale pojavu heterotopičnih osifikacija, retrogradnu ejakulaciju i bol, njihova je klinička primjena ograničena. U ovom smo preglednom radu raspravili otkriće BMP molekula, njihovu biologiju i primjenu u kliničkim studijama s posebnim osvrtom na nedavno otkrivenu novu autolognu koštanu napravu (ABGS) koja sadrži BMP6. Novi ABGS sastoji se od nosača autolognog koaguluma (ABC) s otopljenim BMP6 koji je ključan za pokretanje diferencijacije mezenhimalnih stanica u smjeru stvaranja endohondralne kosti. ABC je ispunio sve potrebne uvjete za formulaciju optimalnog nosača za BMP6 isključivo zbog jednostavnosti priprave i primjene te odsustva imunogenog i upalnog odgovora na mjestu implantacije. Uz dodatak alografta ili sintetičke keramike što je potvrđeno na životinjskim modelima došlo je do značajnog povećanja volumena te poboljšanja mikroarhitekture novonastale kosti. Prvo kliničko ispitivanje provedeno je na pacijentima s distalnim prijelomima radijusa (faza I studije), a drugo na pacijentima koji su podvrgnuti visokoj osteotomiji tibije (faza I/II studije) bez uočenih ozbiljnih nuspojava. Trenutno je u tijeku studija OSTEOproSPINE u kojoj se testira učinkovitost ABGS u kombinaciji s koštanim alograftom u bolesnika s kroničnim bolovima u leđima uzrokovanim degenerativnim promjenama intervertebralnog diska. Nova ABGS koštana naprava značajna je prekretnica i napredak u području koštane biologije te regenerativne medicine koštanog sustava.

KLJUČNE RIJEČI: BMP6, TGF $\beta$ nadobitelj, endohondralno stvaranje kosti, koštani mimetik, distalni prijelom radijusa, visoka osteotomija tibije, posteorolateralna spinalna fuzija, alograft, kronična slabinska bol, regenerativna medicina

\section{INTRODUCTION}

The treatment of broken fractures alone uses almost half of the health care budget in the US and EU ${ }^{1}$. In addition, more than 3 million bone grafting surgeries are performed annually ${ }^{2}$. Out of 6 million fractures in the EU each year, 5-25\% result in impaired healing ${ }^{3}$. These numbers are increasing and might reach 12 million bone fractures by 2050 in EU alone.

Bone morphogenetic proteins (BMPs) induce endochondral bone formation at ectopic and orthotopic sites and since the discovery they represent the most important biological support in bone injuries treatment ${ }^{4-7}$. However, currently used BMP-based bone devices demonstrate numerous safety issues limiting their broader use ${ }^{8-10}$.

An autologous bone graft substitute (ABGS) composed of recombinant human BMP6 (rhBMP6) in autologous blood coagulum $(\mathrm{ABC})$ was developed to support new bone formation and promote bone healing in various orthopedic and trauma indications. Thus, the animal-derived collagen has been replaced with $\mathrm{ABC}$ which reduces the inflammatory response and serves as a physiological carrier for rhBMP6 adjustable to the desired 
shape ${ }^{11,12}$. Based on the results from the preclinical studies, clinical studies/trials in patients with a distal radial fracture, high tibal osteotomy and posterolateral spinal fusion were approved ${ }^{13-15}$. This review covers BMP discovery, biology and their use in clinical studies with particular reference to new BMP6 based ABGS.

\section{DISCOVERY OF BONE MORPHOGENETIC PROTEINS}

Urist discovered that demineralized bone matrix (DBM) is capable of inducing new bone when implanted ectopically in the skeletal muscle ${ }^{16,17}$. He described this phenomenon as "bone formation by autoinduction" which was the first proof that acellular DBM has a bone morphogenic activity that is capable of inducing new bone at ectopic sites.

The progress in identifying BMPs from the DBM has been slow due to the difficulty in isolating proteins from the insoluble bone matrix without a defined bioassay for in vivo inducing bone formation. However, it was then found that proteins inducing bone could be solubilized from DBM by dissociative extraction using $4 \mathrm{M}$ guanidium chloride or $8 \mathrm{M}$ urea. The extracted proteins were then reconstituted with a residual collagenous matrix and implanted under the skin in a rat axillar region ${ }^{18}$ (Fig. 1). In this dissociative extraction and reconstitution procedure, the solubilized extract provided the signals on collagenous scaffold to recruit the mesenchymal stem cells to undergo proliferation and differentiation into new/novel bone at an ectopic site ${ }^{19}$ (Fig. 1). This was the first reproducible bioassay for testing BMPs which helped to discover that the bone forming activity was homologous across the mammals ${ }^{20}$. The isolation, characterization and identification of several BMPs from bone matrix extract became therefore possible. The amino acid sequences obtained from bone inductive protein fractions were isolated from bovine bone ${ }^{21}$. Several genes encoding BMP1, $-2,-3$ and -4 were identified by molecular cloning. BMP2, -3 and -4 were classified as TGF $\beta$ superfamily protein members, while BMP1 was classified as a mammalian tolloid proteinase active in the processing of extracellular matrix proteins, like collagens and certain members of the TGF $\beta$ family, including TGF $\beta$, GDF8 and GDF1 ${ }^{22-28}$. After amino acid sequences conformation of highly purified bovine osteogenic proteins from DBM, an association to Drosophila DPP and Xenopus Vg-1 was established. A consensus gene construct was used to obtain the OP-1 (BMP7) gene for the first time ${ }^{29-31}$. In addition, several BMP genes were cloned ${ }^{32}$ from human cDNA and genomic libraries using oligonucleotide probes whose constructions were derived from known BMP gene sequences and named Growth and Differentiation Factors (GDFs). A set of morphogenetic proteins was identified, including cartilage-derived morphogenetic proteins, CDMPs (also known as CDMP1/ GDF-5/BMP11; CDMP-2/GDF-6/BMP12; CDMP-3/GDF-7/ $\mathrm{BMP} 13)$ expressed predominantly in cartilage and the prostatederived growth factor (PDF/GDF15/MIC-1) originally detected in the prostate tissue ${ }^{33,34}$.

\section{BMP FUNCTION}

Almost all of the BMP molecules function through binding to a specific Ser/Thr kinase receptor heterodimeric complex composed of one type I receptor and one type II receptor ${ }^{35-40}$. The binding of a BMP to its receptor may be facilitated by extracellular matrix proteins like type IV collagen and heparan sulfate proteoglycan, including co-receptors like Endoglin and Hemojuvelin ${ }^{41,42}$. The ligand-receptor complex then induces the phosphorylation of intracellular SMAD1/5/8 proteins to mediate downstream signaling. The binding of BMP to its receptor complex is tightly controlled in the specific microenvironment via endogenous antagonists, like Noggin ${ }^{43,44}$.

BMPs form bone at ectopic and bony sites, but are also expressed in tissues other than bone ${ }^{6,45-48}$. They serve as inductive signals in tissue organogenesis, like cardiac tissue ${ }^{49}$, lung development ${ }^{50}$ and kidney morphogenesis ${ }^{51,52}$. The loss of BMP6 causes hemochromatosis ${ }^{53}$ and gain of BMP6 function results in anemia through disturbance of the iron-hemojuvelin-hepcidin loop ${ }^{53-56}$. The GDF8 loss results in enhanced skeletal myogenesis with high metabolic activity exhibiting a lean phenotype ${ }^{57}$, whereas GDF11 has a positive role in ageing ${ }^{58}$.

Role OF BMPS IN EMBRYOGENESIS AND DEVELOPMENT Noggin, Gremlins, Sclerostin and Chordin as BMP antagonists are important for the mesoderm development and endochondral bone formation ${ }^{7,42,59}$. BMPs and BMP antagonists are simultaneously expressed by cells to form a concentration gradient ${ }^{48,60}$, depending on the anatomical location of bones in the skeleton ${ }^{61}$. To govern the skeletal morphogenesis, BMP-signaling collaborates with activin and TGF- $\beta$, as well as Wnt and Hedgehog signaling ${ }^{60,62,63}$. The identification of BMPs, their receptors and antagonists 17,18,21,31,33,34,38,64-66 led to important studies on BMP use in clinical indications ${ }^{67-76}$. Individual BMPs were analyzed in genetically modified mice mutants and via standard gene targeting studies, as well as overexpression of BMPs, Bone Morphogenetic Protein Receptors (BMPRs) and their signaling molecules, Smads. BMPs collectively play an important part in the skeleton development, as well as the development of the nervous system, liver, kidney, heart, pancreas, eye and germ cells ${ }^{4,45,46,51,77-86}$.

\section{COMMERCIAL BMP-BASED BONE IMPLANTS}

BMPs alone cannot promote formation of bone, unless administered together with an appropriate scaffold and osteoprogenitor cells in a permissive micro environment ${ }^{66,87-91}$. So far animalderived collagens were used as a carrier for BMP2 and BMP7 in clinically approved bone devices, while bovine collagen, cellulose and synthetic ceramics were studied in animals ${ }^{92-94}$. rhBMP2 with bovine collagen was applied in mandibular bone surgery 95,96 and diaphyseal fractures ${ }^{97}$. In posterolateral lumbar fusion (PLF), rhBMP2 on a ceramic-collagen composite did not receive FDA approval since the high dose and the weak binding to collagen-ceramics composite resulted in potentially serious adverse effects ${ }^{98-101}$. 
Both available BMP implants use a bovine collagen as a scaffold and contain BMP2 (Infuse Bone Graft, lumbar tampered fusion device) or BMP7 (Osigraft) ${ }^{102,103}$. Clinical trials led to the approval of BMP2 and BMP7 implants for the long bone acute fracture surgeries, tibial non-unions and anterior spinal fusion ${ }^{9,10,104-113}$. The use of BMP2 based Infuse Bone Graft showed safety issues which restricted its use in patients ${ }^{9,10}$. There is around 2 milligrams of BMPs in the human body. Clinicians used around 12-40 milligrams of BMP2 in patients undergoing spinal fusion surgery. However, when the surgery was performed on the cervical spine, a neck swelling was sometimes present, which led to serious lifethreatening complications ${ }^{9,10}$. Surprisingly, out of milligrams added of BMP2, only about 75 micrograms bound to 1 gram of bovine collagen ${ }^{114}$, while the rest aggregates on the collagen, becoming potentially available to migrate to distant sites to induce heterotopic ossification. Following BMP2 implant use in a posterolateral lumbar fusion indication, complications, such as a nerve injury, retrograde ejaculation and distant ossification were detected $9,10,107,109,111$. Although orthopedic and trauma specialists might use a BMP based product in the majority of patients with osteoporotic bone injuries, safety issues and the price are limiting elements in the routine use of the BMP2 device. These problems with the use of BMP2 and BMP7 based bone implants originate from the limited knowledge about the role of BMPs in bone induction at both ectopic site, like in PLF, or enhanced orthotopic bone formation in long bone fractures and non-unions ${ }^{115}$.

\section{COMMERCIAL BMP-BASED DEVICES CAUSE BONE LOSS AND INFLAMMATION}

BMP2 and BMP7 may cause bone resorption, resulting in implant displacement, subsidence and alignment loss, particularly after human spine surgeries ${ }^{9,10}$. Inflammation and swelling were initially not observed when BMP2 or BMP7 were used in patients with long bone injuries, unless administered close under the skin. In patients undergoing reconstruction surgery of the distal radius, the use of a BMP7 commercial device resulted in bone resorption and skin redness ${ }^{116}$. Similarly, in preclinical studies BMP7 used within the bone medullary canal caused accelerated bone loss ${ }^{117}$.

However, in clinical trials BMP2 and BMP7 supported bone healing with an efficacy similar to autologous bone implants. It was initially shown that BMPs on bovine collagen carrier stimulate bone formation in animals, including rats, mice, rabbits, sheep, goats, dogs, and monkeys ${ }^{64,82,118-122}$. In acute fracture clinical studies, bone loss was not demonstrated following administration of BMP2 and BMP7 ${ }^{104,106}$. Initial evidence of extended bone resorption was found in patients undergoing distal radial surgery reconstructing abnormal bone curvature using BMP7 ${ }^{116}$, and anterior spine approach to replace degenerative discs using BMP2 $9,10,105,108-113$.

Similarly, the intracorporal use of BMP7 in thoracolumbar fractures led to pronounced bone loss and segmental instability
123-126. However, the initial bone loss was not permanent and the bone formation with subsequent regeneration was observed ${ }^{9,10}$.

\section{Cellular compartments influencing the BMP- INDUCED BONE FORMATION}

BMPs primarily stimulate differentiation of the cells comprising the periosteum cell layers and the adjacent muscles to support the fracture healing from outside of the medullary canal. BMPs can thus ossify muscles through downregulating the Id genes ${ }^{83,127-129}$, and subsequently turn pericytes and myoblasts into osteogenic cells (Fig. 2) ${ }^{130}$. Therefore, the bone callus originates primarily form the periosteal cells and the surrounding muscle based cells that initiate bone formation adjacent to the lateral long bone diaphyseal surfaces. The stimulation of osteoclasts inside the bone shaft is critical for resorption of bone fragments accumulated following a fracture inside the bone canal. Therefore, osteolysis happens endostealy ${ }^{117}$, new bone is made outside the bone canal and mechanically supports both bone ends via the callus constructed of the periosteal stem cells and osteoprogenitors from the adjacent tissues (Fig. 2). The outcome of the use of BMP2 and BMP7 in initial clinical studies for acute fractures and non-unions of long bones was not successful due to the lack of soft tissues around the distal tibia, potential disruption of the periosteum, and a potential presence of an infection ${ }^{78}$. The BMP2 and BMP7 amounts in available BMP devices represent a biological overdose of both proteins, resulting in increased bioavailability distantly and leading potentially to unexpected immunological reactions, antibody formation, ectopic bone appearance, etc. 9,10,115,131,132.

\section{Autologous bone graft SUbstitute: A nEW BONE GRAFT MIMETIC CONTAINING RHBMP6 AND A PATIENT'S OWN BLOOD COAGULUM AS A NATURAL BMP CARRIER}

The BMPs initiates a biological response depending on the surrounding cells and the extracellular matrix present at the site of delivery. In injured bone osteoprogenitor cells come from various tissue compartments comprising the periosteum, bone marrow, vasculature and the adjacent musculature. All these cell populations contribute to bone healing, but how they respond to various BMPs is yet to be explored (Fig. 3) 79,80,104,133,134.

Enhanced osteogenesis without bone resorption at the site of implantation of osteogenic device is critical to advance use of BMPs in acceleration of bone healing with pronounced bone formation. Periosteal bone formation in the vicinity of bone and at ectopic site in an osteoclast free environment is a prerequisite for the full $\mathrm{BMP}$ action on bone repair or bone induction in an ectopic soft tissue environment, like PLF in spine surgery (Fig. 2).

The novel ABGS osteogenic device accelerates bone repair and contains compatible blood coagulum carrier, thus limiting inflammatory reaction contrary to other BMP based bone devices. BMP6 is used in a small dose with the ABC carrier and enhanced bone formation in preclinical studies ${ }^{14,135-138}$ (Figs. 1, 3, and 4). 
A

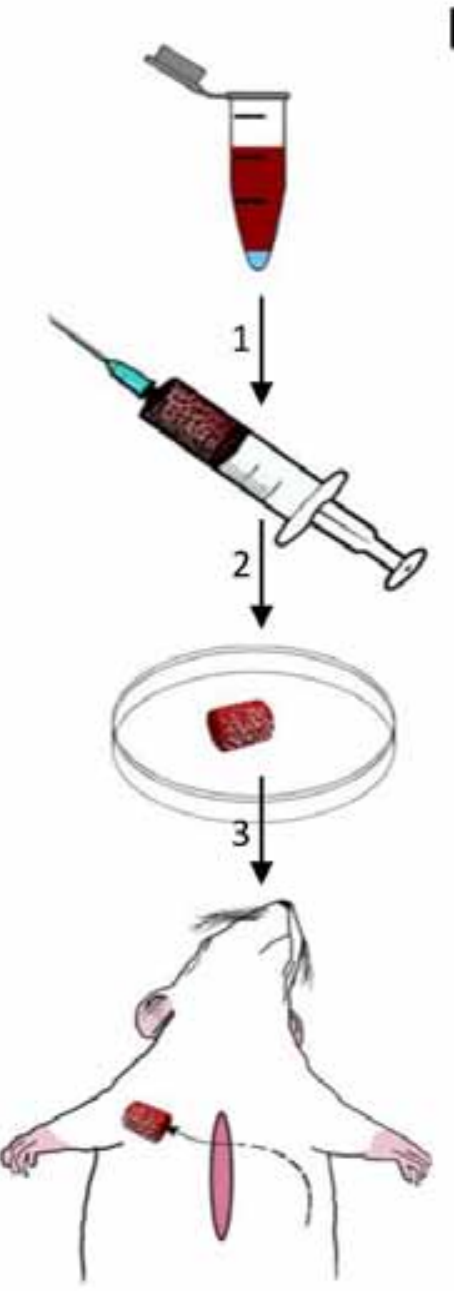

B
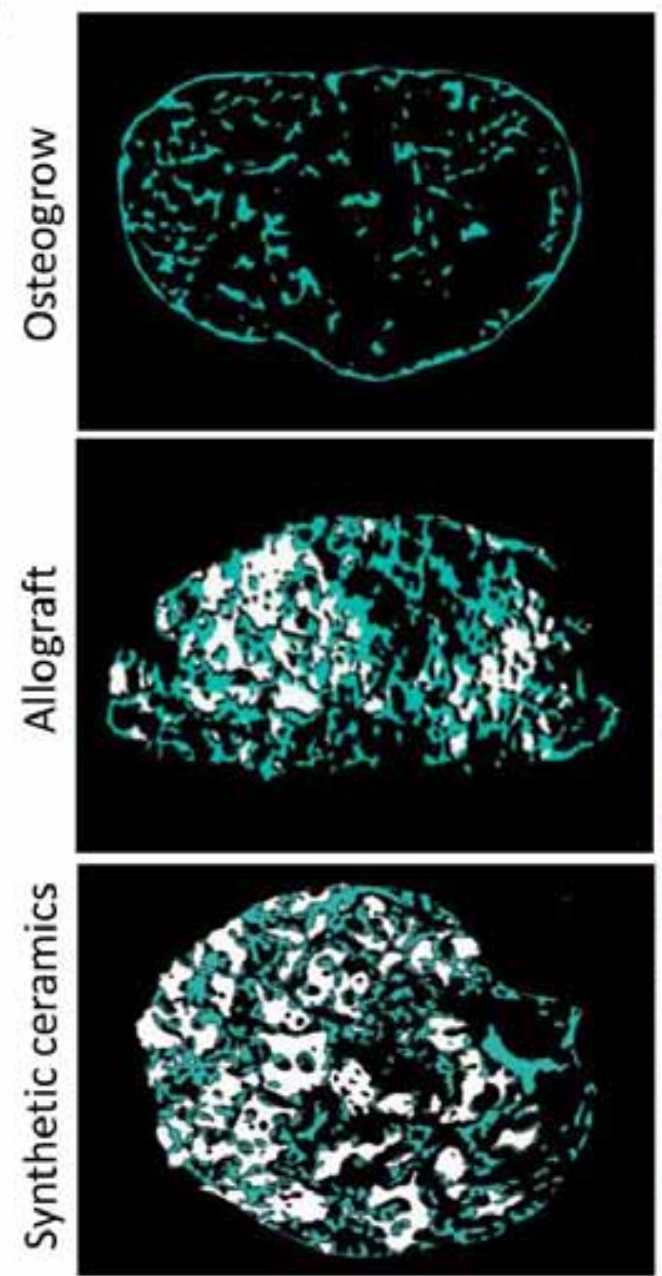
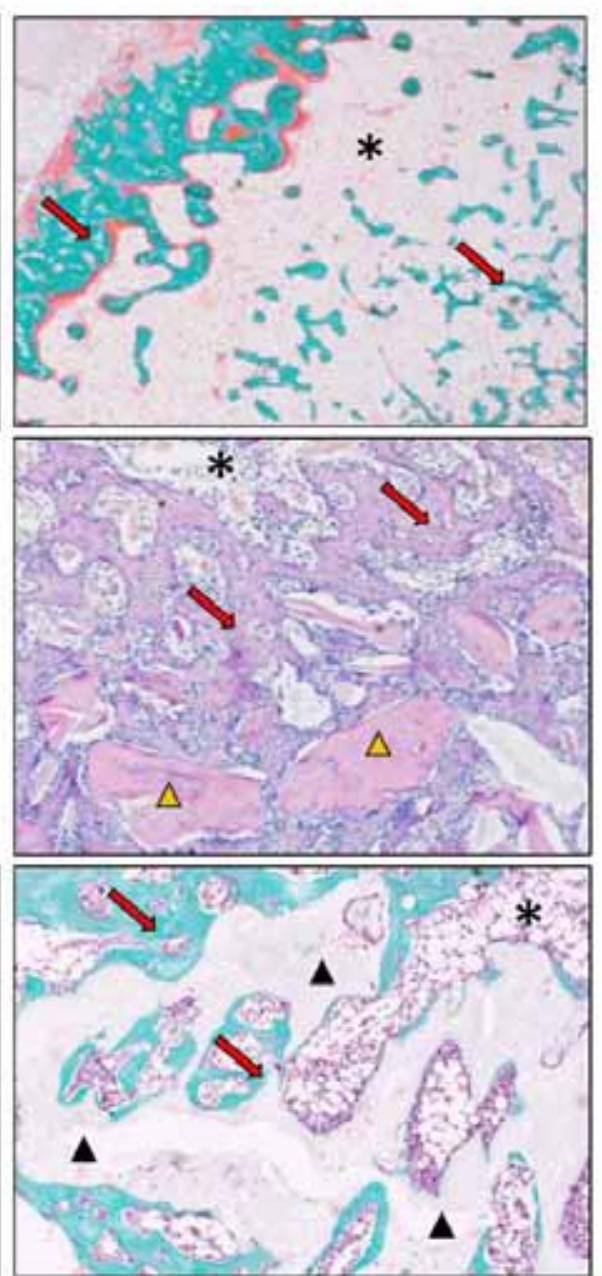

Figure 1. Histological and $\mu \mathrm{CT}$ analysis of new bone formation using ABGS and different compression resistant matrices. (A) Implant preparation scheme; 1 - blood was drawn in a volume of $500 \mu \mathrm{L}$ per implant and was transferred to the tube with an aliquoted solution of rhBMP6 and gently mixed; blood with rhBMP6 was drawn into the syringe containing CRM; 2 - final product (ABGS containing CRM) left on room temperature to coagulate; 3 - subcutaneous implantation into the axillary region in rats. (B) Left column - reconstruction images of CT sections where green indicates newly formed bone and white areas indicates CRM - allograft (middle row) or synthetic ceramics (lower row). Right column - histology sections (Goldner trichrome and hematoxylin-eosin staining); red arrow - newly formed bone, black asterisk - bone marrow, yellow triangle - allograft, black triangle - synthetic ceramics. (Modified from Stokovic N, et al. Bone 141:115654, 2020) 


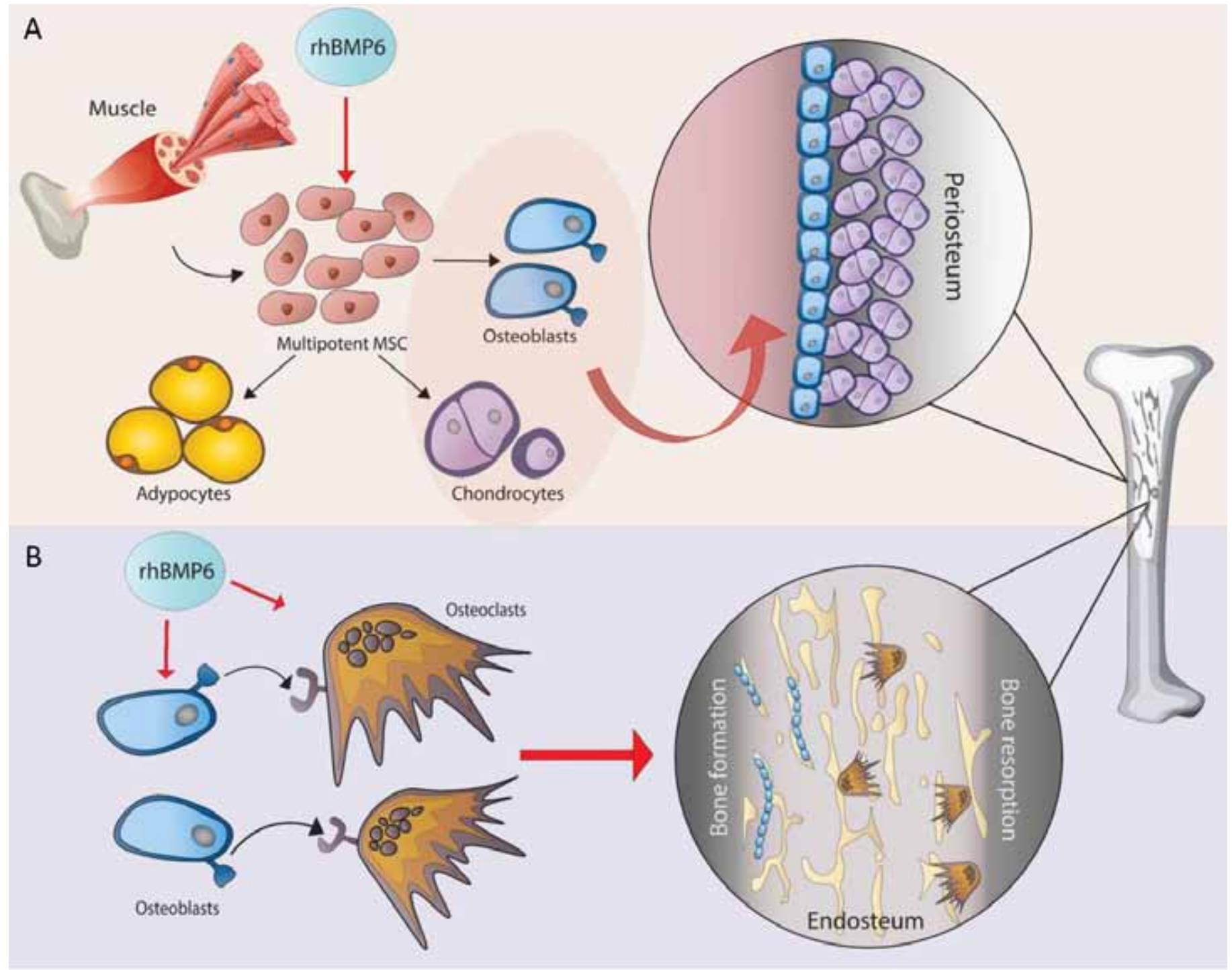

Figure 2. In vivo effect of rhBMP6. (A) Uncoupled bone formation; at the periosteum, rhBMP6 stimulates differentiation of multipotent mesenchymal stem cells (MSC) into osteoblasts, chondrocytes, and adipocytes; in surrounding muscle cells (myoblasts, pericytes, and vascular satellite cells) rhBMP6 upregulates $I d$ genes and form new osteoblasts and prechondrocytes to form cartilage and new bone around the cortical surface from which the new bone spreads into the medullar cavity. (B) Coupled bone formation; at the endosteal surface rhBMP6 affects osteoclasts and osteoblasts stimulating both bone formation and resorption. 

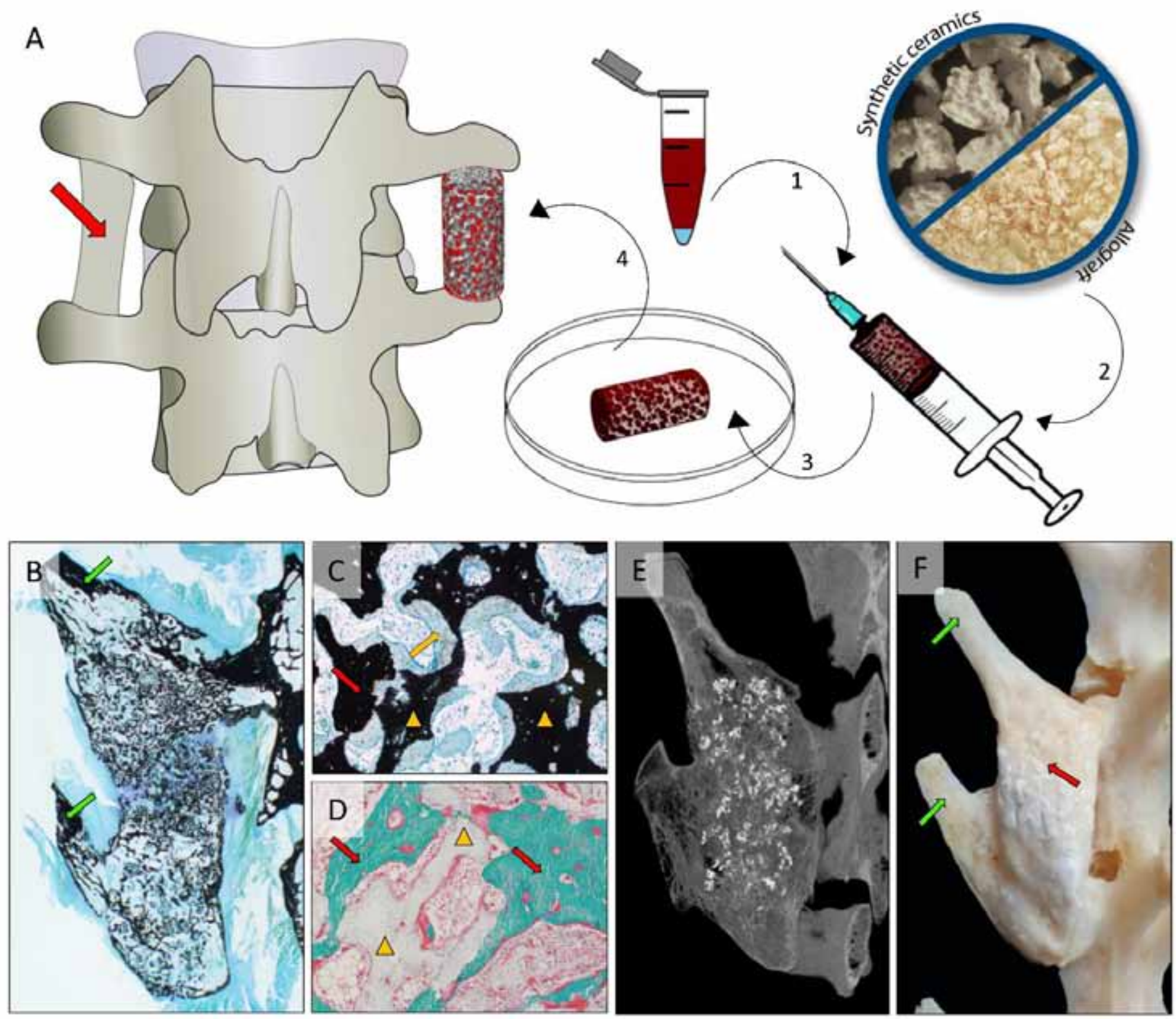

Figure 3. Assessment of the effectiveness of the compression resistant matrix (CRM) in the new bone formation. (A) Implant preparation scheme; 1 - rhBMP6 solution was mixed with blood; 2 - blood with rhBMP6 was drawn into the syringe containing CRM; 3 the implant was left at room temperature to coagulate; 4 - implantation between two lumbar transverse processes; a red arrow indicates a fusion of lumbar transverse processes. (B) Histological section (Von Kossa staining) of newly formed bone between two transverse processes (green arrows). (C) Histological presentation of newly formed bone integrated with ceramic particles (Von Kossa staining); the yellow triangle indicates ceramic particles, the red arrow indicates newly formed mineralized bone, while the yellow arrow indicates unmineralized bone. (D) Newly formed bone integrated with ceramic particles (Goldner Trichrome staining); the yellow triangle indicates ceramic particles while the bone is turquoise (red arrows). (E) $\mu \mathrm{CT}$ section through newly formed bone between two transverse processes. (F) Macerated specimen of the lumbar spine showing fusion (red arrow) between two transverse processes (green arrows). (Modified from Sampath TK, Vukicevic S. Bone 115602, 2020; Stokovic N, et al. Bone 140:115544, 2020; and Vukicevic S, et al. J Tissue Eng Reg Med 14:147-159, 2020) 
A
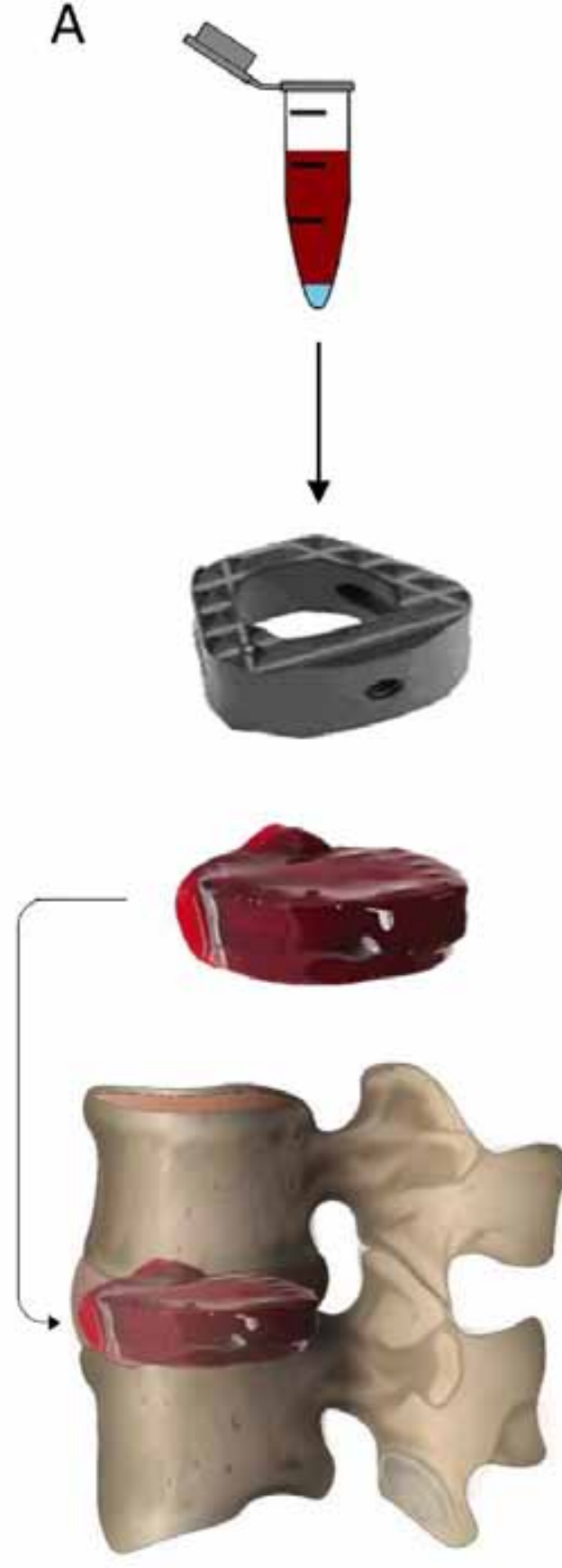
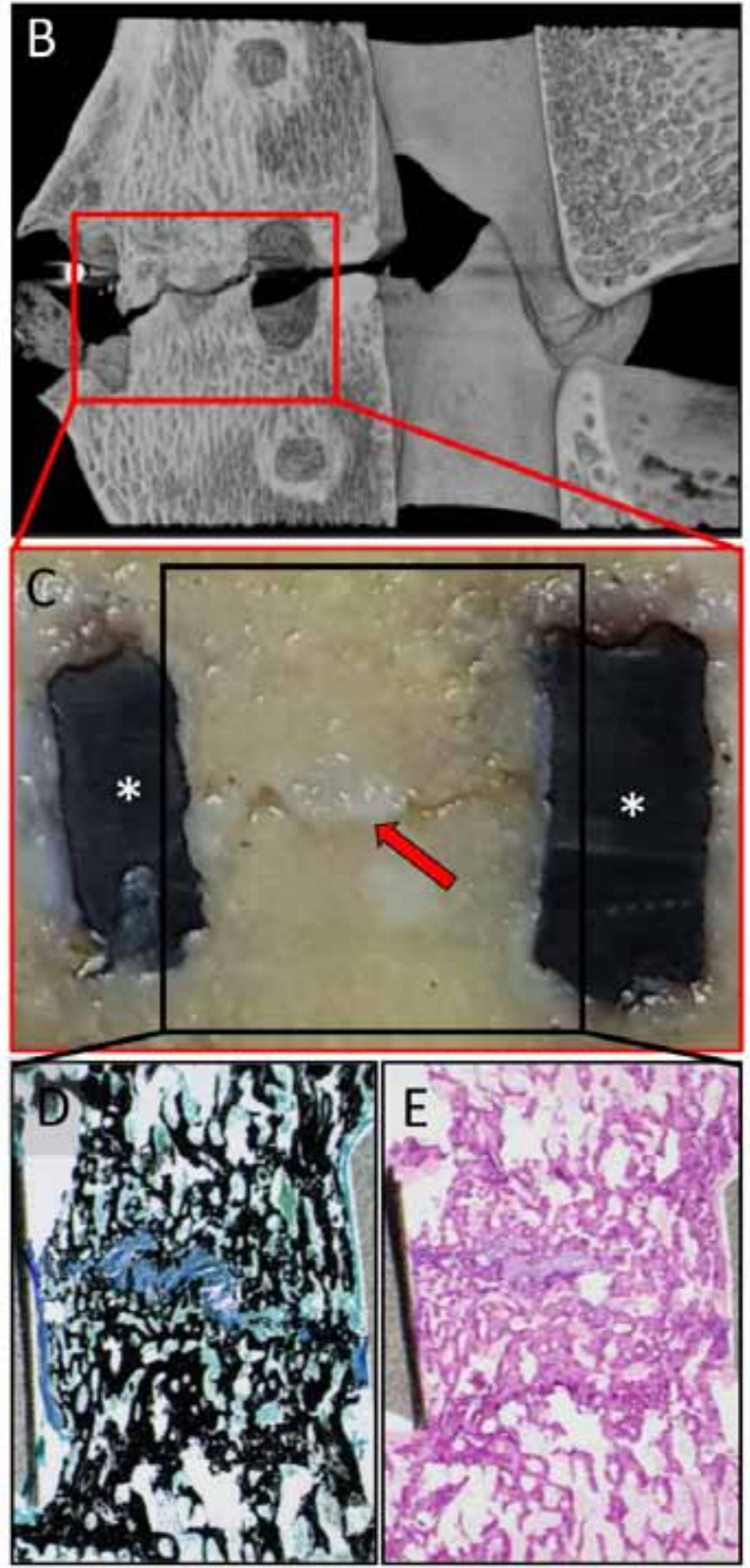

Figure 4. Testing of novel ABGS in anterior lumbar interbody fusion in sheep. (A) Implant preparation scheme; $1.5 \mathrm{~mL}$ of blood was drawn from the sheep jugular vein and mixed with rhBMP6 solution. The cage was immersed into the blood/rhBMP6 mixture and left at room temperature to coagulate for 60 minutes after it was implanted in between body of L4-L5 vertebrae. (B) 3D reconstruction of two fused vertebrae. (C) Macroscopic image of two fused vertebrae where red arrow indicates the fusion line and white asterisks indicate the cage. (D) Histology section stained by Von Kossa and (E) hematoxylin-eosin. (Modified from Grgurevic L, et al. Bone 138: 115448, 2020) 


\section{Uniqueness of BMP6}

We have designed and developed a novel bone osteogenic device based on BMP6 delivered in an autologous bone coagulum as a natural carrier and tested its safety and efficacy in a rat subcutaneous assay (Fig. 1), in rabbit PLF (Fig. 3), and in sheep anterior interbody fusion (ALIF) (Fig. 4) and PLF models.

BMP6 is specific in directing stem cells to cartilage and bone osteoprogenitors ${ }^{85,139-141}$. BMP6 differs from BMP7 structure in the $\mathrm{H} 3$ pre-helix loop region (residues $65-73)^{142}$. BMP6 and $\mathrm{BMP7}$ also seem to use different BMP receptor type I, resulting in BMP6 expressing a 20-fold increased affinity to BMPR-IA, in comparison to BMP7. BMP6 shares, however, several binding and signaling receptor specificities with BMP7 ${ }^{69,143}$. A resistance of BMP6 to Noggin explains why much larger amounts of BMP7 are required in the BMP7-containing bone device for successful bone regeneration in primates and patients ${ }^{6,43,139}$. Importantly, the mice lacking $B m p 6-/$ - gene are viable and fertile 144, while mice lacking $B m p 7-/$-gene are eyeless and die of uremia due to failed development of kidney mesenchyme ${ }^{145,146}$. This might suggest that potential development and presence of an anti BMP6 antibody following use of ABGS might result in less harm than an anti BMP7 antibody following use of Ossigraft in patients.

BMP6 effectively induces differentiation of mesenchymal stem cells (MSCs) towards osteoprogenitor cells in the in vitro bone formation, compared to BMP2 and BMP7 in bone marrow cells ${ }^{88,147}$. In parallel, BMP6 decreases the number of hematopoietic stem cells (HSC) derived osteoclasts, while an opposite effect of BMP2 and BMP7 has been observed ${ }^{140}$. Using liquid chromatography-mass spectrometry (LC-MS) and Western blotting ${ }^{148}$ we found that BMP6 was circulating in the blood of healthy mice and humans ${ }^{23}$. In addition, osteoporotic rats treated with BMP6 had an increased bone volume, suggesting that BMP6 is systemically influencing bone homeostasis ${ }^{149}$. The genomic experiments revealed that treatment with BMP6 resulted in an enrichment of IGF1 and EGF related pathways, which was confirmed on primary human osteoblasts, indicating that the effect of BMP6 is at least partially dependent of IGF1 and EGF pathway ${ }^{140}$. Alteration of the plasma membrane heparan-sulfate (HS) structure inhibited BMP6-mediated signaling in $\mathrm{C}_{2} \mathrm{C}_{12}$ premyoblast mouse cell line, preventing differentiation into osteoblasts. Endogenous HS thus has an important role in the BMP6 biology. Exogenous heparin did not recover BMP6 signaling in HS-altered $\mathrm{C}_{2} \mathrm{C}_{12}$ cells, suggesting that cell membrane $\mathrm{HS}$ is needed for the appropriate BMP6 signaling in normal ${ }^{54,150}$ and in pathological conditions ${ }^{151}$.

BMP6 bone repair in Bmp6-/- mice increased the differentiation of bone marrow accumulated stem cells towards chondrocytes and alkaline phosphatase positive bone forming cells ${ }^{12,24,43,85,139}$. These specific structural and functional characteristics of BMP6 supported its use in the novel ABGS device.
BMP6 quantity needed for treatment of mice lacking Bmp6 gene Pre-clinical studies showed that BMP6 can be used in a much lower quantity than BMP2 and BMP7. We demonstrated that $50 \mu \mathrm{g}$ BMP6 in the ABGS implant is more effective than 3.5 mg of BMP7 in the Osigraft in studies on rabbit ulna segmental bone defect ${ }^{131}$. When BMP2, BMP6 and BMP7 were used in similar amounts in a biocompatible ABGS in rabbits with a segmental bone defect, BMP6 showed the best healing properties without evident osteolysis. In rat, fibrosis and an inflammatory response were not present at a subcutaneous site ${ }^{131,132}$ (Fig. 1) due to the higher BMP6 potency associated to a lesser sensitivity to Noggin ${ }^{43}$. BMP6 dissociates from Noggin, following binding of the BMP-Noggin complex to the cell surface receptors type I 43. BMP2, BMP7 and BMP6 have different capacity for binding to Noggin that is based on structural differences. In BMP6, at position 60 of the mature domain is a lysine aminoacid, essential for reversible binding to Noggin. Furthermore, if the proline at position 60 in BMP2 and BMP7 is replaced with lysine, the osteogenic activity of both BMPs significantly increased ${ }^{43}$. This might also prolong the BMP6 half-life time activity resulting in an enhanced osteoblast differentiation beneficial for the fracture healing ${ }^{152}$.

\section{Autologous blood coagulum as a BMPG physiological carrier} $\mathrm{ABC}$ from the patient's own blood is a novel autologous carrier for BMPs ${ }^{138}$. ABGS is non-immunogenic, non-inflammatory and without bovine collagen, opposite to commercially available devices. It is a flexible, compact, malleable, cohesive, and easy to inject material, not disassembling into parts for at least 7 days after implantation ${ }^{115,131}$. In preclinical animal models of bone regeneration ABGS successfully bridged the segmental bone defects ${ }^{12,115,131}$. At low dose ABGS induces new bone when implanted under the skin (Fig. 1), promotes diaphyseal segmental defects healing and induces PLF in rabbits ${ }^{131,132}$ (Fig. 3) and sheep ${ }^{135}$ (Fig. 4). In the absence of rhBMP6, ABC implantation resulted in absence of new bone and instead formed a fibrous tissue which dissolved over time ${ }^{131}$.

BMP6 was selected for ABGS because it reversibly binds to Noggin ${ }^{43}$ and thus helps to lower the BMP dose. For signaling BMP6 uses ALK2, ALK3 and ALK6 BMP type I receptors and it increases the expression of bone differentiation markers in cell cultures ${ }^{131,140}$. ABC also decreases inflammation and foreign body cell accumulation when combined with allograft or calcium phosphate ceramics in PLF animal studies ${ }^{132,135,136,153}$. BMP6 in blood remains active for approximately 7 days and could not be detected in the remaining serum after the formation of the autologous blood coagulum ${ }^{12,115,131}$. BMP6 is bound to the ABGS extracellular matrix as well as cell membranes included in the ABGS ${ }^{12,131}$. These findings served as a basis for formulating ABGS. 


\section{Compression resistant matrix}

To improve biomechanical properties of ABGS, compression resistant matrix (CRM) might be added to ABGS implants in selected indications which require larger implants including PLF and segmental defects of long bones ${ }^{132}$. Allograft was the first CRM tested in combination with ABGS in rabbit and sheep PLF models ${ }^{132,135}$. Following the successful outcome of these preclinical studies, ABGS formulation with allograft particles as a CRM is being currently tested in PLF clinical study in patients with degenerative disc disease. However, allograft possesses several disadvantages including viral transmission risk, immunogenicity and regulatory issues ${ }^{154}$. Therefore, to overcome these shortcomings we evaluated calcium phosphate synthetic ceramics as a CRM in rat subcutaneous implant assay and rabbit PLF model. Calcium phosphate ceramics might be composed of tricalcium phosphate (TCP) or hydroxyapatite (HA) while the main difference between them is their resorption characteristics (TCP is significantly more resorbable than HA). TCP and HA might be combined in biphasic calcium phosphate with different TCP/HA ratios to obtain the desired CRM resorption characteristics. Synthetic ceramics might be formulated into varioussize particles or blocks. We have demonstrated that addition of synthetic ceramics to ABGS significantly increased the amount of newly formed bone and decreased the outcome variability ${ }^{137,153}$. Moreover, we have demonstrated that size and shape of ceramic particles determines the quantity and microarchitecture of the newly formed bone ${ }^{137}$. ABGS with synthetic ceramic particles was successfully used in a rabbit PLF model ${ }^{136}$. Tested ABGS formulations induced formation of new bone and osteointegration with native transverse processes.

\section{Clinical studies using ABGS}

In clinical trials we tested whether the low quantities of BMP6 in an autologous carrier support trabecular bone healing of the compartment in which BMP2 and BMP7 were ineffective ${ }^{14,15}$. ABGS has so far been tested in Phase I study in patients with distal radial fractures ${ }^{14}$ and Phase I/II study in patients undergoing high tibial osteotomy ${ }^{15}$.

\section{Distal radial fracture healing study}

The novel ABGS composed of rhBMP6 within an ABC as a homologous carrier was tested for safety and efficacy in patients having a distal radial fracture (DRF). Thirty two patients were enrolled in a randomized, double-blinded Phase I First in Human $(\mathrm{FiH})$ clinical trial with standard of care $(\mathrm{SoC})$ and placebo (PBO) controlled therapeutic arms. ABGS was made from peripheral $\mathrm{ABC}$ with $250 \mu \mathrm{g} \mathrm{rhMP} 6 / \mathrm{mL}$ or $\mathrm{PBO}(1 \mathrm{~mL} \mathrm{ABC}$ with excipients only) and was applied dorsally via injection into the fracture area following fixation with 3 Kirschner wires. The patient's arm was immobilized for 5 weeks and the patient was followed for 26 weeks by clinical observations, radiographic im- aging and CT. No serious adverse reactions were recorded at any observation time point. No detectable anti-rhBMP6 antibodies in the plasma of any of the 32 patients at 13- and 26-weeks following treatment were detected. Patients treated with rhBMP6/ $\mathrm{ABC}$ showed enhanced bone healing in comparison to $\mathrm{PBO}$ and SoC at 5 and 9 weeks. Finally, we showed that intraosseous use of ABGS in the distal radial fracture site accelerated the cancellous bone repair without any serious adverse events ${ }^{14}$.

\section{High tibial osteotomy clinical study}

BMP6 dispersed in ABC was administered into a surgically created wedge defect of the proximal tibia to patients undergoing high tibial osteotomy (HTO) for varus deformity and medial compartment osteoarthritis of the knee. Twenty HTO patients received rhBMP6/ABC or placebo in a randomized, $\mathrm{PBO}-$ controlled, double-blinded Phase I/II clinical study. Patients were then followed for 24 months by clinical observation, CT and radiographic imaging. It was demonstrated that there were no anti-rhBMP6 antibodies in the plasma of any of the 20 patients at 14 weeks after implantation. No serious adverse events were recorded during the 24 months of follow-up. Patients treated with rhBMP6/ABC showed an enhanced bone healing at 9 weeks and at 14 weeks follow-up. At weeks 6 and 24 and months 12 and 24 increased bone formation and advanced bone remodeling in rhBMP6/ABC-treated patients were observed on radiographic images. This is the first demonstration of a BMPbased osteogenic implant tested against a placebo for bone repair in the cancellous bone, using a novel and objective bone mineral density measurement system ${ }^{15}$.

\section{Posterolateral spine fusion study in patients with degenerative disc disease}

The ongoing study is evaluating the application of ABGS in patients with chronic back pain due to degenerative disc disease. In the OSTEOproSPINE study patients are treated with a novel bone regeneration therapy composed of rhBMP 6 delivered in $\mathrm{ABC}$ reinforced with allograft (a compression resistant matrix). It is aimed to guide bone formation at an extraskeletal site and replace autograft harvested from patient's iliac crest for lumbar vertebrae fusion. This Phase II, randomized, double-blinded clinical trial included three clinical centers to enroll 134 patients. A positive outcome of the study would confirm the potential of ABGS as a substitute for iliac crest graft to form a functional new bone in humans and restore the spine function to improve the quality of life in patients with a degenerative disc disease ${ }^{13}$.

\section{CONCLUSION}

BMPs are growth and differentiation factors belonging to the TGF $\beta$ superfamily of proteins. They are synthetized, folded as dimeric proteins in the cell cytoplasm, further cleaved by proteases during secretion. Their activity is elicited after binding to 
heteromeric type I and II serine/threonine kinase receptors that activates the signal transduction via Smad 1, 5 and 8, forming a complex with Smad 4 to enter the nucleus. BMP molecules induce ectopic and orthotopic endochondral bone formation and have multiple roles in regulation of cell proliferation, differentiation, apoptosis and mesenchymal-epithelial interactions during critical morphogenetic processes in tissues other than bone. Bone formation induced by the novel ABGS serves as a prototype for tissue engineering, with the $\mathrm{ABC}$ acting as a substrate with dispersed BMP6 to initiate the differentiation of mesenchymal cells into endochondral bone. The $\mathrm{ABC}$ met the conditions for an optimal delivery system for BMP6 with handling simplicity, retaining the BMP device at the site of implantation without an immunogenic and inflammatory response. BMP6 reversibly binds to the BMP antagonist Noggin, which ensures the efficacy of a low dose of BMP contained in the ABC. Further optimization of the ABGS focused on providing a product resistant to compression to maintain a uniform size and shape of the ABGS implants in patients treated for various bone disorders. Addition of allograft or synthetic ceramics to ABGS demonstrated in animal PLF models significantly increased volume and better microarchitecture of the newly formed bone. The first demonstration of an ABGS effect on the repair of cancellous bone was tested in patients with DRF (Phase I study) and in patients undergoing HTO (Phase I/II study) without any serious adverse events.
Intraosseous use of ABGS in the cancellous bone repair resulted in an enhanced and accelerated bone healing. In the ongoing OSTEOproSPINE study ABGS enforced with allograft bone is evaluated in patients with chronic back pain due to the degenerative disc disease. The novel ABGS autologous bone mimetic represents a major breakthrough and contribution to regenerative medicine and bone biology.

\section{CONFLICT OF INTEREST}

L.G., H.O. and S.V. have an issued patent US8197840 licensed to Genera Research. T.K.S. received grants from perForm Biologics during the study. H.O. is Genera Research employee and CEO. Other authors do not declare conflict of interest.

\section{ACKNOWLEDGEMENTS}

This program was funded by the European Community's Seventh Framework (FP7/2007-2013) under grant agreement HEALTH-F4-2011-279239 (Osteogrow), Horizon 2020 GA No 779340 (OSTEOproSPINE) and the Scientific Center of Excellence for Reproductive and Regenerative Medicine (project "Reproductive and regenerative medicine-exploration of new platforms and potentials" GA KK.01.1.1.01.0008 funded by the EU through the ERDF). 


\section{LITERATURE:}

1. The American College of Surgeons. National Trauma Data Bank Report. 2002.

2. Deutsche Bank Alex. Brown estimates and company information. 2001.

3. American Academy of Orthopaedic Surgeons. Musculoskeletal injuries report: incidence, risk factors and prevention. 2000.

4. Vukicevic S, Sampath TK. Bone Morphogenetic Proteins: From Laboratory to Clinical Practice. Basel-Boston-Berlin: Birkhauser Verlag. 2002.

5. Vukicevic S, Sampath TK. Bone Morphogenetic Proteins: Regeneration of Bone and Beyond. Basel-Boston-Berlin: Birkhauser Verlag. 2004.

6. Vukicevic S, Sampath TK. Bone morphogenetic proteins: from local to systemic therapeutics. Basel-Boston-Berlin: Birkauser Verlag AG. 2008.

7. Vukicevic S, Sampath KT. Bone Morphogenetic Proteins: Systems Biology Regulators. Springer International Publishing. 2017.

8. Dumic-Cule I, Peric M, Kucko L, Grgurevic L, Pecina M, Vukicevic S. Bone morphogenetic proteins in fracture repair. Int Orthop. 2018;42:2619-2626.

9. Fu R, Selph S, McDonagh M, Peterson K, Tiwari A, Chou R, et al. Effectiveness and Harms of Recombinant Human Bone Morphogenetic Protein-2 in Spine Fusion: A Systematic Review and Meta-analysis. Ann Intern Med. 2013;158:890-902.

10. Simmonds MC, Brown JV, Heirs MK, Higgins JP, Mannion RJ, Rodgers MA, et al. Safety and Effectiveness of Recombinant Human Bone Morphogenetic Protein-2 for Spinal Fusion: A Meta-analysis of Individual-Participant Data. Ann Intern Med. 2013;158:877-889.

11. Grgurevic L, Vukicevic S. OSTEOGROW - novel bone device for bone regeneration. Rad Hrvatske akademije znanosti i umjetnosti: Medicinski razred. 2018;533:71-80.

12. Grgurevic L, Erjavec I, Dumic-Cule I, Bordukalo-Niksic T, Pauk M, Trkulja V, et al. Osteogrow: A Novel Bone Graft Substitute for Orthopedic Reconstruction. In: Vukicevic S, Sampath TK, editors. Bone Morphogenetic Proteins: Systems Biology Regulators. Springer International Publishing. 2017; 215-228.

13. HORIZON 2020. Novel bone regeneration drug osteogrow: Therapeutic solution for lumbar back pain - OSTEOproSPINE. GA:779340. 2017.

14. Durdevic D, Vlahovic T, Pehar S, Miklic D, Oppermann H,

Bordukalo-Niksic T, et al. A novel autologous bone graft substitute comprised of rhBMP6 blood coagulum as carrier tested in a randomized and controlled Phase I trial in patients with distal radial fractures. Bone. 2020;140:115551.

15. Chiari C, Grgurevic L, Bordukalo-Niksic T, Oppermann H, Valentinitsch A, Nemecek E, et al. Recombinant Human BMP6 Applied Within Autologous Blood Coagulum Accelerates Bone Healing: Randomized Controlled Trial in High Tibial Osteotomy Patients. J Bone Miner Res. 2020. doi: 10.1002/jbmr.4107

16. Grgurevic L, Pecina M, Vukicevic S. Marshall R. Urist and the discovery of bone morphogenetic proteins. Int Orthop. 2017;41:1065-1069.

17. Urist MR. Bone: formation by autoinduction. Science.

1965;150:893-899.
18. Sampath TK, Reddi AH. Dissociative extraction and reconstitution of extracellular matrix components involved in local bone differentiation. Proc Natl Acad Sci USA. 1981;78:7599-7603.

19. Reddi AH, Huggins C. Biochemical sequences in the transformation of normal fibroblasts in adolescent rats. Proc Natl Acad Sci USA. 1972;69:1601-1605.

20. Sampath TK, Reddi AH. Homology of bone-inductive proteins from human, monkey, bovine, and rat extracellular matrix. Proc Natl Acad Sci USA. 1983;80:6591-6595.

21. Wozney JM, Rosen V, Celeste AJ, Mitsock LM, Whitters MJ, Kriz RW, et al. Novel regulators of bone formation: molecular clones and activities. Science. 1988;242:1528-1534.

22. Dumic-Cule I, Colliva A, Kufner V, Martinelli V, Moimas S, Vodret $\mathrm{S}$, et al. Bone Morphogenetic Protein 1.3 isoform inhibition supports cardiomyocyte survival and decreases scar formation after acute myocardial infarction in rodents. Proc Natl Acad Sci USA. In press

23. Grgurevic L, Macek B, Healy DR, Brault AL, Erjavec I, Cipcic A, et al. Circulating bone morphogenetic protein 1-3 isoform increases renal fibrosis. J Am Soc Nephrol. 2011;22:681-692.

24. Grgurevic L, Macek B, Mercep M, Jelic M, Smoljanovic T, Erjavec I, et al. Bone morphogenetic protein (BMP) 1-3 enhances bone repair. Biochem Biophys Res Commun. 2011;408:25-31.

25. Grgurevic L, Erjavec I, Grgurevic I, Dumic-Cule I, Brkljacic J, Verbanac D, et al. Systemic inhibition of BMP1-3 decreases progression of CCl4-induced liver fibrosis in rats. Growth Factors. 2017;35:201-215.

26. Kessler E, Takahara K, Biniaminov L, Brusel M, Greenspan DS. Bone morphogenetic protein-1: the type I procollagen C-proteinase. Science. 1996;271:360-362.

27. Kobayashi K, Luo M, Zhang Y, Wilkes DC, Ge G, Grieskamp T, et al. Secreted Frizzled-related protein 2 is a procollagen $\mathrm{C}$ proteinase enhancer with a role in fibrosis associated with myocardial infarction. Nat Cell Biol. 2009;11:46-55.

28. Muir A, Greenspan DS. Metalloproteinases in Drosophila to humans that are central players in developmental processes. J Biol Chem. 2011;286:41905-41911.

29. Sampath TK, Maliakal JC, Hauschka PV, Jones WK, Sasak H, Tucker $\mathrm{RF}$, et al. Recombinant human osteogenic protein-1 (hOP-1) induces new bone formation in vivo with a specific activity comparable with natural bovine osteogenic protein and stimulates osteoblast proliferation and differentiation in vitro. J Biol Chem. 1992;267:20352-20362.

30. Celeste AJ, Iannazzi JA, Taylor RC, Hewick RM, Rosen V, Wang EA, et al. Identification of transforming growth factor beta family members present in bone-inductive protein purified from bovine bone. Proc Natl Acad Sci USA. 1990;87:9843-9847.

31. Ozkaynak E, Rueger DC, Drier EA, Corbett C, Ridge RJ, Sampath TK, et al. OP-1 cDNA encodes an osteogenic protein in the TGF-beta family. EMBO J. 1990;9:2085-2093.

32. Lee SJ. Identification of a novel member (GDF-1) of the transforming growth factor-beta superfamily. Mol Endocrinol. 1990;4:1034-1040.

33. Paralkar VM, Vail AL, Grasser WA, Brown TA, Xu H, Vukicevic S, et al. Cloning and characterization of a novel member of the transform- 
ing growth factor-beta/bone morphogenetic protein family. J Biol Chem. 1998;273:13760-13767.

34. Chang SC, Hoang B, Thomas JT, Vukicevic S, Luyten FP, Ryba NJ, et al. Cartilage-derived morphogenetic proteins. New members of the transforming growth factor-beta superfamily predominantly expressed in long bones during human embryonic development. J Biol Chem. 1994;269:28227-28234.

35. Sanchez-Duffhues G, Williams E, Goumans MJ, Heldin CH, Ten DP. Bone morphogenetic protein receptors: Structure, function and targeting by selective small molecule kinase inhibitors. Bone. 2020;138:115472. 36. Salazar VS, Gamer LW, Rosen V. BMP signalling in skeletal development, disease and repair. Nat Rev Endocrinol. 2016;12:203-221. 37. da Silva MC, Jatzlau J, Knaus P. BMP signalling in a mechanical context - Implications for bone biology. Bone. 2020;137:115416. 38. ten Dijke P, Yamashita H, Sampath TK, Reddi AH, Estevez M, Riddle $\mathrm{DL}$, et al. Identification of type I receptors for osteogenic protein-1 and bone morphogenetic protein-4. J Biol Chem. 1994;269:16985-16988. 39. Heldin CH, Miyazono K, Ten DP. TGF-beta signalling from cell membrane to nucleus through SMAD proteins. Nature. 1997;390:465-471. 40. Massague J. TGF-beta signal transduction. Annu Rev Biochem. 1998;67:753-791.

41. Babitt JL, Huang FW, Wrighting DM, Xia Y, Sidis Y, Samad TA, et al. Bone morphogenetic protein signaling by hemojuvelin regulates hepcidin expression. Nat Genet. 2006;38:531-539.

42. Paralkar VM, Vukicevic S, Reddi AH. Transforming growth factor beta type 1 binds to collagen IV of basement membrane matrix: implications for development. Dev Biol. 1991;143:303-308.

43. Song K, Krause C, Shi S, Patterson M, Suto R, Grgurevic L, et al. Identification of a key residue mediating bone morphogenetic protein (BMP)-6 resistance to noggin inhibition allows for engineered BMPs with superior agonist activity. J Biol Chem. 2010;285:12169-12180.

44. Yanagita M. Bone morphogenetic protein antagonists and kidney. In: Vukicevic S, Sampath TK, editors. Bone morphogenetic proteins: From local to systemic therapeutics. Basel, Boston, Berlin: Birkhauser. 2008; 213-232.

45. Helder MN, Ozkaynak E, Sampath KT, Luyten FP, Latin V, Oppermann $\mathrm{H}$, et al. Expression pattern of osteogenic protein-1 (bone morphogenetic protein-7) in human and mouse development. J Histochem Cytochem. 1995;43:1035-1044.

46. Helder MN, Karg H, Bervoets TJ, Vukicevic S, Burger EH, D‘Souza $\mathrm{RN}$, et al. Bone morphogenetic protein-7 (osteogenic protein-1, OP-1) and tooth development. J Dent Res. 1998;77:545-554.

47. Vukicevic S, Latin V, Chen P, Batorsky R, Reddi AH, Sampath TK. Localization of osteogenic protein-1 (bone morphogenetic protein-7)

during human embryonic development: high affinity binding to basement membranes. Biochem Biophys Res Commun. 1994;198:693-700. 48. Bier E, De Robertis EM. EMBRYO DEVELOPMENT. BMP gradients: A paradigm for morphogen-mediated developmental patterning. Science. 2015;348:aaa5838.

49. Zhang H, Bradley A. Mice deficient for BMP2 are nonviable and have defects in amnion/chorion and cardiac development. Development. 1996;122:2977-2986.
50. Bellusci S, Henderson R, Winnier G, Oikawa T, Hogan BL. Evidence from normal expression and targeted misexpression that bone morphogenetic protein (Bmp-4) plays a role in mouse embryonic lung morphogenesis. Development. 1996;122:1693-1702.

51. Vukicevic S, Kopp JB, Luyten FP, Sampath TK. Induction of nephrogenic mesenchyme by osteogenic protein 1 (bone morphogenetic protein 7). Proc Natl Acad Sci USA. 1996;93:9021-9026.

52. Vukicevic S, Basic V, Rogic D, Basic N, Shih MS, Shepard A, et al. Osteogenic protein-1 (bone morphogenetic protein-7) reduces severity of injury after ischemic acute renal failure in rat. J Clin Invest. 1998;102:202-214.

53. Andriopoulos B, Jr., Corradini E, Xia Y, Faasse SA, Chen S, Grgurevic $\mathrm{L}$, et al. BMP6 is a key endogenous regulator of hepcidin expression and iron metabolism. Nat Genet. 2009;41:482-487.

54. Brkljacic J, Pauk M, Erjavec I, Cipcic A, Grgurevic L, Zadro R, et al. Exogenous heparin binds and inhibits bone morphogenetic protein 6 biological activity. Int Orthop. 2013;37:529-541.

55. Pauk M, Grgurevic L, Brkljacic J, Kufner V, Bordukalo-Niksic T, Grabusic K, et al. Exogenous BMP7 corrects the plasma iron overload and bone loss in Bmp6-/- mice. Int Orthop. 2015;39:161-172.

56. Pauk M, Bordukalo-Niksic T, Brkljacic J, Paralkar VM, Brault AL, Dumic-Cule I, et al. A novel role of bone morphogenetic protein 6 (BMP6) in glucose homeostasis. Acta Diabetol. 2019;56:365-371. 57. McPherron AC, Lawler AM, Lee SJ. Regulation of skeletal muscle mass in mice by a new TGF-beta superfamily member. Nature. 1997;387:83-90.

58. Sinha M, Jang YC, Oh J, Khong D, Wu EY, Manohar R, et al. Restoring systemic GDF11 levels reverses age-related dysfunction in mouse skeletal muscle. Science. 2014;344:649-652.

59. Matsuda S, Harmansa S, Affolter M. BMP morphogen gradients in flies. Cytokine Growth Factor Rev. 2016;27:119-127.

60. Hogan BL. Bone morphogenetic proteins in development. Curr Opin Genet Dev. 1996;6:432-438.

61. Zhang H, Zhang Y, Terajima M, Romanowicz G, Liu Y, Omi M, et al. Loss of BMP signaling mediated by BMPR1A in osteoblasts leads to differential bone phenotypes in mice depending on anatomical location of the bones. Bone. 2020;137:115402.

62. Kishigami S, Mishina Y. BMP signaling and early embryonic patterning. Cytokine Growth Factor Rev. 2005;16:265-278.

63. Hwang C, Pagani CA, Das N, Marini S, Huber AK, Xie L, et al. Activin A does not drive post-traumatic heterotopic ossification. Bone. 2020;138:115473.

64. Vukicevic S, Stavljenic A, Pecina M. Discovery and clinical applications of bone morphogenetic proteins. Eur J Clin Chem Clin Biochem. 1995;33:661-671.

65. Vukicevic S, Luyten FP, Reddi AH. Stimulation of the expression of osteogenic and chondrogenic phenotypes in vitro by osteogenin. Proc Natl Acad Sci USA. 1989;86:8793-8797.

66. Lissenberg-Thunnissen SN, de Gorter DJ, Sier CF, Schipper IB.

Use and efficacy of bone morphogenetic proteins in fracture healing. Int Orthop. 2011;35:1271-1280. 
67. Graf D, Economides AN. Dissection of bone morphogenetic protein signalling using genome engineering tools. In: Vukicevic S, Sampath TK, editors. Bone Morphogenetic Proteins: From Local to Systemic Therapeutics. Basel-Boston-Berlin: Birkhauser Verlag. 2008; 115-140.

68. Aspenberg P, Basic N, Tagil M, Vukicevic S. Reduced expression of BMP-3 due to mechanical loading: a link between mechanical stimuli and tissue differentiation. Acta Orthop Scand. 2000;71:558-562.

69. Sieber C, Schwaerzer GK, Knaus P. Bone morphogenetic protein signalling is fine-tuned on multiple levels. In: Vukicevic S, Sampath TK, editors. Bone Morphogenetic Proteins: From Local to Systemic Therapeutics. Basel-Boston-Berlin: Birkhauser Verlag. 2008; 81-114.

70. Anticevic D, Jelic M, Vukicevic S. Treatment of a congenital pseudarthrosis of the tibia by osteogenic protein-1 (bone morphogenetic protein-7): a case report. J Pediatr Orthop B. 2006;15:220-221.

71. Bilic R, Simic P, Jelic M, Stern-Padovan R, Dodig D, van Meerdervoort HP, et al. Osteogenic protein-1 (BMP-7) accelerates healing of scaphoid non-union with proximal pole sclerosis. Int Orthop. 2006;30:128-134.

72. Dorai H, Vukicevic S, Sampath TK. Bone morphogenetic protein-7 (osteogenic protein-1) inhibits smooth muscle cell proliferation and stimulates the expression of markers that are characteristic of SMC phenotype in vitro. J Cell Physiol. 2000;184:37-45.

73. Grgic M, Jelic M, Basic V, Basic N, Pecina M, Vukicevic S. Regeneration of articular cartilage defects in rabbits by osteogenic protein-1 (bone morphogenetic protein-7). Acta Med Croatica. 1997;51:23-27.

74. Jelic M, Pecina M, Haspl M, Kos J, Taylor K, Maticic D, et al. Regeneration of articular cartilage chondral defects by osteogenic protein-1 (bone morphogenetic protein-7) in sheep. Growth Factors. 2001;19:101113 .

75. Mihelic R, Pecina M, Jelic M, Zoricic S, Kusec V, Simic P, et al. Bone morphogenetic protein-7 (osteogenic protein-1) promotes tendon graft integration in anterior cruciate ligament reconstruction in sheep. Am J Sports Med. 2004;32:1619-1625.

76. de Gorter DJ, Krause C, Lowik CWGM, Bezooijen RL, ten Dijke P. Control of bone mass by sclerostin: inhibiting BMP- and WNT-induced bone formation. In: Vukicevic S, Sampath TK, editors. Bone Morphogenetic Proteins: From Local to Systemic Therapeutics. Basel-Boston-Berlin: Birkhauser Verlag. 2008; 257-276.

77. Katagiri T, Boorla S, Frendo JL, Hogan BL, Karsenty G. Skeletal abnormalities in doubly heterozygous Bmp4 and Bmp7 mice. Dev Genet. 1998;22:340-348.

78. Friedlander C, Nerubay J, Katznelson A, Nebel L. Osteogenesis by periosteal transplant. Experimental study of spinal fusion in rats. Isr J Med Sci. 1979;15:38-42.

79. Pecina M, Giltaij LR, Vukicevic S. Orthopaedic applications of osteogenic protein-1 (BMP-7). Int Orthop. 2001;25:203-208.

80. Pecina M, Haspl M, Jelic M, Vukicevic S. Repair of a resistant tibial non-union with a recombinant bone morphogenetic protein-7 (rhBMP-7). Int Orthop. 2003;27:320-321.

81. Perry MJ, McDougall KE, Hou SC, Tobias JH. Impaired growth plate function in bmp-6 null mice. Bone. 2008;42:216-225.
82. Ripamonti U, Vukicevic S. Bone morphogenetic proteins: from developmental biology to molecular therapeutics. S Afr J Sci. 91, 277-280. 1995.

83. Simic P, Vukicevic S. Bone morphogenetic proteins: from developmental signals to tissue regeneration. Conference on bone morphogenetic proteins. EMBO Rep. 2007;8:327-331.

84. ten Dijke P. Bone morphogenetic protein signal transduction in bone. Curr Med Res Opin. 2006;22 Suppl 1:S7-11.

85. Vukicevic S, Grgurevic L. BMP-6 and mesenchymal stem cell differentiation. Cytokine Growth Factor Rev. 2009;20:441-448.

86. Simic P, Vukicevic S. BMPs in development. In: Vukicevic S, Pecina M, editors. Bone Morphogenetic Proteins: Regeneration of Bone and Beyond. Basel-Boston-Berlin: Birkhauser Verlag. 2004; 73-108.

87. Auregan JC, Begue T. Induced membrane for treatment of critical sized bone defect: a review of experimental and clinical experiences. Int Orthop. 2014.

88. Martinovic S, Borovecki F, Miljavac V, Kisic V, Maticic D, Francetic I, et al. Requirement of a bone morphogenetic protein for the maintenance and stimulation of osteoblast differentiation. Arch Histol Cytol. 2006;69:23-36.

89. Giannoudis PV, Einhorn TA, Marsh D. Fracture healing: a harmony of optimal biology and optimal fixation? Injury. 2007;38 Suppl 4:S1-S2. 90. Giannoudis PV, Gudipati S, Harwood P, Kanakaris NK. Long bone non-unions treated with the diamond concept: a case series of 64 patients. Injury. 2015;46 Suppl 8:S48-S54.

91. Pecina M, Vukicevic S. Tissue engineering and regenerative orthopaedics (TERO). Int Orthop. 2014;38:1757-1760.

92. Seeherman HJ, Li XJ, Smith E, Wozney JM. rhBMP-2/calcium phosphate matrix induces bone formation while limiting transient bone resorption in a nonhuman primate core defect model. J Bone Joint Surg Am. 2012;94:1765-1776.

93. Seeherman HJ, Li XJ, Smith E, Parkington J, Li R, Wozney JM. Intraosseous injection of rhBMP-2/calcium phosphate matrix improves bone structure and strength in the proximal aspect of the femur in chronic ovariectomized nonhuman primates. J Bone Joint Surg Am. 2013;95:3647.

94. Petrauskaite O, Gomes PS, Fernandes MH, Juodzbalys G, Stumbras A, Maminskas J, et al. Biomimetic mineralization on a macroporous cellulose-based matrix for bone regeneration. Biomed Res Int. 2013;2013:452750.

95. Cicciu M, Herford AS, Cicciu D, Tandon R, Maiorana C. Recombinant human bone morphogenetic protein-2 promote and stabilize hard and soft tissue healing for large mandibular new bone reconstruction defects. J Craniofac Surg. 2014;25:860-862.

96. Herford AS, Tandon R, Stevens TW, Stoffella E, Cicciu M. Immediate distraction osteogenesis: the sandwich technique in combination with rhBMP-2 for anterior maxillary and mandibular defects. J Craniofac Surg. 2013;24:1383-1387.

97. A Randomized Controlled Trial Comparing rhBMP-2/Absorbable Collagen Sponge Versus Autograft for the Treatment of Tibia Fractures With Critical Size Defects. J Orthop Trauma. 2019;33:384-391. 
98. Hwang CJ, Vaccaro AR, Lawrence JP, Hong J, Schellekens H, AlaouiIsmaili $\mathrm{MH}$, et al. Immunogenicity of bone morphogenetic proteins. J Neurosurg Spine. 2009;10:443-451.

99. Molina CS, Stinner DJ, Obremskey WT. Treatment of Traumatic Segmental Long-Bone Defects: A Critical Analysis Review. J Bone Joint Surg Rev. 2014;2.

100. Aspenberg P, Jeppsson C, Economides AN. The bone morphogenetic proteins antagonist Noggin inhibits membranous ossification. J Bone Miner Res. 2001;16:497-500.

101. Benevenia J, Kirchner R, Patterson F, Beebe K, Wirtz DC, Rivero S, et al. Outcomes of a Modular Intercalary Endoprosthesis as Treatment for Segmental Defects of the Femur, Tibia, and Humerus. Clin Orthop Relat Res. 2016;474:539-548.

102. Bishop GB, Einhorn TA. Current and future clinical applications of bone morphogenetic proteins in orthopaedic trauma surgery. Int Orthop. 2007;31:721-727.

103. White AP, Vaccaro AR, Hall JA, Whang PG, Friel BC, McKee MD. Clinical applications of BMP-7/OP-1 in fractures, nonunions and spinal fusion. Int Orthop. 2007;31:735-741.

104. Govender S, Csimma C, Genant HK, Valentin-Opran A, Amit Y, Arbel R, et al. Recombinant human bone morphogenetic protein-2 for treatment of open tibial fractures: a prospective, controlled, randomized study of four hundred and fifty patients. J Bone Joint Surg Am. 2002;84A:2123-2134.

105. Burkus JK, Transfeldt EE, Kitchel SH, Watkins RG, Balderston RA. Clinical and radiographic outcomes of anterior lumbar interbody fusion using recombinant human bone morphogenetic protein-2. Spine (Phila Pa 1976). 2002;27:2396-2408.

106. Friedlaender GE, Perry CR, Cole JD, Cook SD, Cierny G, Muschler GF, et al. Osteogenic protein-1 (bone morphogenetic protein-7) in the treatment of tibial nonunions. J Bone Joint Surg Am. 2001;83-A Suppl 1:S151-S158.

107. Axelrad TW, Steen B, Lowenberg DW, Creevy WR, Einhorn TA. Heterotopic ossification after the use of commercially available recombinant human bone morphogenetic proteins in four patients. J Bone Joint Surg Br. 2008;90:1617-1622.

108. Boden SD, Zdeblick TA, Sandhu HS, Heim SE. The use of rhBMP-2 in interbody fusion cages. Definitive evidence of osteoinduction in humans: a preliminary report. Spine (Phila Pa 1976). 2000;25:376381.

109. Carragee EJ, Mitsunaga KA, Hurwitz EL, Scuderi GJ. Retrograde ejaculation after anterior lumbar interbody fusion using rhBMP-2: a cohort controlled study. Spine J. 2011;11:511-516.

110. Hiremath GK, Steinmetz MP, Krishnaney AA. Is it safe to use recombinant human bone morphogenetic protein in posterior cervical fusion? Spine (Phila Pa 1976). 2009;34:885-889.

111. Kang JD. Another complication associated with rhBMP-2? Spine J. 2011;11:517-519.

112. Kleeman TJ, Ahn UM, Talbot-Kleeman A. Laparoscopic anterior lumbar interbody fusion with rhBMP-2: a prospective study of clinical and radiographic outcomes. Spine (Phila Pa 1976). 2001;26:2751-2756.
113. Mroz TE, Wang JC, Hashimoto R, Norvell DC. Complications related to osteobiologics use in spine surgery: a systematic review. Spine (Phila Pa 1976). 2010;35:S86-104.

114. Chatzinikolaidou M, Lichtinger TK, Muller RT, Jennissen HP. Periimplant reactivity and osteoinductive potential of immobilized rhBMP-2 on titanium carriers. Acta Biomater. 2010;6:4405-4421.

115. Vukicevic S, Oppermann H, Verbanac D, Jankolija M, Popek I, Curak J, et al. The clinical use of bone morphogenetic proteins (BMPs) revisited: A novel BMP6 biocompatible carrier device OSTEOGROW for bone healing. Int Orthop. 2014;38:635-647.

116. Ekrol I, Hajducka C, Court-Brown C, McQueen MM. A comparison of rhBMP-7 (OP-1) and autogenous graft for metaphyseal defects after osteotomy of the distal radius. Injury. 2008;39 Suppl 2:S73-S82. 117. McGee MA, Findlay DM, Howie DW, Carbone A, Ward P, Stamenkov $\mathrm{R}$, et al. The use of OP-1 in femoral impaction grafting in a sheep model. J Orthop Res. 2004;22:1008-1015.

118. Ripamonti U, Heliotis M, Ferretti C. Bone morphogenetic proteins and the induction of bone formation: from laboratory to patients. Oral Maxillofac Surg Clin North Am. 2007;19:575-89, vii.

119. Cook SD. Preclinical and clinical evaluation of osteogenic protein-1 (BMP-7) in bony sites. Orthopedics. 1999;22:669-671.

120. Seeherman H, Wozney JM. Delivery of bone morphogenetic proteins for orthopedic tissue regeneration. Cytokine Growth Factor Rev. 2005;16:329-345.

121. Cook SD, Rueger DC. Preclinical models of recombinant BMP induced healing of orthopedic defects. In: Vukicevic S, Sampath TK, editors. Bone Morphogenetic Proteins From Laboratory to Clinical Practice. Basel-Boston-Berlin: Birkhauser Verlag. 2002; 121-144.

122. Blokhuis TJ, Patka P, Haarman H.J.Th.M., Giltaij LR. Osteogenic protein-1 (OP-1, BMP-7) for stimulation of healing of closed fractures: evidence based medicine and pre-clinical experience. In: Vukicevic $S$, Sampath TK, editors. Bone Morphogenetic Proteins From Laboratory to Clinical Practice. Basel-Boston-Berlin: Birkhauser Verlag. 2002; 145-156. 123. Laursen M, Hoy K, Hansen ES, Gelineck J, Christensen FB, Bunger $\mathrm{CE}$. Recombinant bone morphogenetic protein-7 as an intracorporal bone growth stimulator in unstable thoracolumbar burst fractures in humans: preliminary results. Eur Spine J. 1999;8:485-490.

124. Hansen SM, Sasso RC. Resorptive response of rhBMP2 simulating infection in an anterior lumbar interbody fusion with a femoral ring. J Spinal Disord Tech. 2006;19:130-134.

125. Pradhan BB, Bae HW, Dawson EG, Patel VV, Delamarter RB. Graft resorption with the use of bone morphogenetic protein: lessons from anterior lumbar interbody fusion using femoral ring allografts and recombinant human bone morphogenetic protein-2. Spine (Phila Pa 1976 ). 2006;31:E277-E284.

126. Poynton AR, Lane JM. Safety profile for the clinical use of bone morphogenetic proteins in the spine. Spine (Phila Pa 1976 ). 2002;27:S40-S48.

127. Katagiri T, Imada M, Yanai T, Suda T, Takahashi N, Kamijo R. Identification of a BMP-responsive element in Id1, the gene for inhibition of myogenesis. Genes Cells. 2002;7:949-960. 
128. Katagiri T, Akiyama S, Namiki M, Komaki M, Yamaguchi A, Rosen $\mathrm{V}$, et al. Bone morphogenetic protein-2 inhibits terminal differentiation of myogenic cells by suppressing the transcriptional activity of MyoD and myogenin. Exp Cell Res. 1997;230:342-351.

129. Katagiri T, Yamaguchi A, Komaki M, Abe E, Takahashi N, Ikeda $\mathrm{T}$, et al. Bone morphogenetic protein-2 converts the differentiation pathway of C2C12 myoblasts into the osteoblast lineage. J Cell Biol. 1994;127:1755-1766.

130. Nojima J, Kanomata K, Takada Y, Fukuda T, Kokabu S, Ohte $S$, et al. Dual roles of smad proteins in the conversion from myoblasts to osteoblastic cells by bone morphogenetic proteins. J Biol Chem. 2010;285:15577-15586.

131. Grgurevic L, Oppermann H, Pecin M, Erjavec I, Capak H, Pauk $\mathrm{M}$, et al. Recombinant Human Bone Morphogenetic Protein 6 Delivered Within Autologous Blood Coagulum Restores Critical Size Segmental Defects of Ulna in Rabbits. JBMR Plus. 2019;3:e10085.

132. Vukicevic S, Grgurevic L, Erjavec I, Pecin M, Bordukalo-Niksic T, Stokovic N, et al. Autologous blood coagulum is a physiological carrier for BMP6 to induce new bone formation and promote posterolateral lumbar spine fusion in rabbits. J Tissue Eng Regen Med. 2020;14:147-159.

133. Swiontkowski MF, Aro HT, Donell S, Esterhai JL, Goulet J, Jones A, et al. Recombinant human bone morphogenetic protein-2 in open tibial fractures. A subgroup analysis of data combined from two prospective randomized studies. J Bone Joint Surg Am. 2006;88:1258-1265.

134. Minear S, Leucht P, Miller S, Helms JA. rBMP represses Wnt signaling and influences skeletal progenitor cell fate specification during bone repair. J Bone Miner Res. 2010;25:1196-1207.

135. Grgurevic L, Erjavec I, Gupta M, Pecin M, Bordukalo-Niksic T, Stokovic N, et al. Autologous blood coagulum containing rhBMP6 induces new bone formation to promote anterior lumbar interbody fusion (ALIF) and posterolateral lumbar fusion (PLF) of spine in sheep. Bone. 2020;138:115448.

136. Stokovic N, Ivanjko N, Pecin M, Erjavec I, Karlovic S, Smajlovic A, et al. Evaluation of synthetic ceramics as compression resistant matrix to promote osteogenesis of autologous blood coagulum containing recombinant human bone morphogenetic protein 6 in rabbit posterolateral lumbar fusion model. Bone. 2020;140:115544.

137. Stokovic N, Ivanjko N, Erjavec I, Milosevic M, Oppermann H, Shimp L, et al. Autologous bone graft substitute containing rhBMP6 within autologous blood coagulum and synthetic ceramics of different particle size determines the quantity and structural pattern of bone formed in a rat subcutaneous assay. Bone. 2020;141:115654.

138. Vukicevic S, Grgurevic L, Oppermann H, inventors. Whole blood-derived coagulum device for treating bone defects. patent US 8197840. 2012. 139. Bernardo ME, Emons JA, Karperien M, Nauta AJ, Willemze R, Roelofs $\mathrm{H}$, et al. Human mesenchymal stem cells derived from bone marrow display a better chondrogenic differentiation compared with other sources. Connect Tissue Res. 2007;48:132-140.

140. Grasser WA, Orlic I, Borovecki F, Riccardi KA, Simic P, Vukicevic S, et al. BMP-6 exerts its osteoinductive effect through activation of IGF-I and EGF pathways. Int Orthop. 2007;31:759-765.
141. Sammons J, Ahmed N, El-Sheemy M, Hassan HT. The role of BMP-6, IL-6, and BMP-4 in mesenchymal stem cell-dependent bone development: effects on osteoblastic differentiation induced by parathyroid hormone and vitamin D3. Stem Cells Dev. 2004;13:273-280.

142. Allendorph GP, Isaacs MJ, Kawakami Y, Izpisua Belmonte JC, Choe S. BMP-3 and BMP-6 structures illuminate the nature of binding specificity with receptors. Biochemistry. 2007;46:12238-12247.

143. Korchynskyi O, van Bezooijen RL, Lowik CWGM, ten Dijke P. Bone morphogenetic protein receptors and their nuclear effectors in bone formation. In: Vukicevic S, Sampath TK, editors. Bone morphogenetic proteins: regeneration of bone and beyond. Basel-Boston-Berlin: Birkauser Verlag. 2004; 9-114.

144. Perry MJ, McDougall KE, Hou SC, Tobias JH. Impaired growth plate function in bmp-6 null mice. Bone. 2008;42:216-225.

145. Dudley AT, Lyons KM, Robertson EJ. A requirement for bone morphogenetic protein-7 during development of the mammalian kidney and eye. Genes Dev. 1995;9:2795-2807.

146. Luo G, Hofmann C, Bronckers AL, Sohocki M, Bradley A, Karsenty G. BMP-7 is an inducer of nephrogenesis, and is also required for eye development and skeletal patterning. Genes Dev. 1995;9:2808-2820. 147. Martinovic S, Mazic S, Kisic V, Basic N, Jakic-Razumovic J, Borovecki $\mathrm{F}$, et al. Expression of bone morphogenetic proteins in stromal cells from human bone marrow long-term culture. J Histochem Cytochem. 2004;52:1159-1167.

148. Grgurevic L, Macek B, Erjavec I, Mann M, Vukicevic S. Urine release of systemically administered bone morphogenetic protein hybrid molecule. J Nephrol. 2007;20:311-319.

149. Simic P, Culej JB, Orlic I, Grgurevic L, Draca N, Spaventi R, et al. Systemically administered bone morphogenetic protein- 6 restores bone in aged ovariectomized rats by increasing bone formation and suppressing bone resorption. J Biol Chem. 2006;281:25509-25521.

150. Denardo A, Elli S, Federici S, Asperti M, Gryzik M, Ruzzenenti P, et al. BMP6 binding to heparin and heparan sulfate is mediated by $\mathrm{N}$ terminal and C-terminal clustered basic residues. Biochim Biophys Acta Gen Subj. 2020;129799.

151. Cuellar A, Reddi AH. Cell biology of osteochondromas: Bone morphogenic protein signalling and heparan sulphates. Int Orthop. 2013;37:1591-1596.

152. de Gorter DJ, van Dinther M, Korchynskyi O, ten Dijke P. Biphasic effects of transforming growth factor beta on bone morphogenetic protein-induced osteoblast differentiation. J Bone Miner Res. 2011;26:11781187.

153. Stokovic N, Ivanjko N, Milesevic M, Matic J, I, Bakic K, Rumenovic $\mathrm{V}$, et al. Synthetic ceramic macroporous blocks as a scaffold in ectopic bone formation induced by recombinant human bone morphogenetic protein 6 within autologous blood coagulum in rats. Int Orthop. 2020. doi: 10.1007/s00264-020-04847-9

154. Mroz TE, Joyce MJ, Lieberman IH, Steinmetz MP, Benzel EC, Wang JC. The use of allograft bone in spine surgery: is it safe? Spine J. 2009;9:303-308. 